\title{
The Effectiveness of National Economic Stimulus as a Countercyclical Policy of Covid-19 Outbreak
}

\author{
Wenny Megawati ${ }^{1}$ \\ Faculty of Law \\ Stikubank University \\ Semarang, Indonesia \\ wennymegawati@edu.unisbank.ac.id \\ Rochmani $^{2}$ \\ Faculty of Law \\ Stikubank University \\ Semarang, Indonesia \\ rochmani@edu.unisbank.ac.id
}

\begin{abstract}
President Joko Widodo asserted measures to mitigate the economic repercussions due to the COVID-19 outbreak. The Financial Services Authority administers a credit relief as stipulated in POJK Regulation No. 11/POJK.03/2020 concerning National Economic Stimulus as Countercyclical Policy to the Coronavirus Disease 2019 Outbreak ("POJK 11/2020") to foster economic growth for debtors affected by the COVID-19. Micro, Small, and Medium Enterprises (MSMEs) debtors and banks are consequently permitted to grant relaxation in respect of credit requirements or to restructure loans. This study aimed to examine the national economic stimulus policy made by the Financial Services Authority (OJK, in Indonesia). Additionally, this study investigated the effectiveness of these measures
\end{abstract}

Keywords: policy, stimulus, restructuring, debtors, banks

\section{INTRODUCTION}

The spread of the coronavirus disease 2019 (COVID-19) widely affects the Indonesian economy, including increased bank credit risk. Debtors had gone through enormous struggles, especially ones in micro, small, and medium enterprises (MSMEs) category. Directly or indirectly, businesses across sectors underwent new challenges unseen before. Concerning the increased risk in the middle of this pandemic, it was alarmed that the prolonged condition may disrupt banking performance and financial system stability, affecting economic growth. A policy is needed to regulate economic system stability.

President Joko Widodo announced mitigation measures by providing a credit relief policy to debtors affected by this pandemic.

The policy endeavored to optimize the banking intermediation function, maintain financial system stability, and support economic growth. Accordingly, the Financial Services Authority issued POJK Regulation No. 11/POJK.03/2020 concerning National Economic Stimulus as Countercyclical Policy to the Coronavirus Disease 2019 Outbreak ("POJK 11/2020"). The legal basis for this countercyclical policymaking are Act Number 7 of 1992 concerning Banking as amended by Act Number 10 of 1998; Act Number 21 of 2008 concerning Islamic Banking; and Act Number 21 of 2011 concerning the Financial Services Authority.

The countercyclical policy can be defined as a strategy that goes against the flow of the business cycle. The proposition implies that during a recession, the government implements expansionary policies in fiscal and monetary easing.[1] The countercyclical policy should be executed temporarily and needs to be evaluated and adjusted.[2] It is crucial to comprehend how banks implement the policy and how effective it may help people affected by Corona Virus Disease 2019 (Covid-19.

\section{METHOD}

We employed the normative law (juridical normative/doctrinal) method, which proposes that law is conceptualized as norms, rules, principles, or dogmas. The approach method is a research procedure of legal, scientific logic, which implies a problem-solving procedure where data is obtained from literature observations, secondary data and subsequently compiled, explained, and analyzed by providing conclusions.[3]

\section{RESULT AND DISCUSSION}

A. Implementation of the national economic stimulus policy enacted by the Financial Services Authority

The measure designed by the government aimed to help debtors affected by the COVID-19 pandemic and maintain national financial stability. Financial Services Authority (FSA) issued POJK Regulation No. 11/POJK.03/2020 concerning National Economic Stimulus as Countercyclical Policy to the Coronavirus Disease 2019 Outbreak.

According to the Minister of Economy, Sri Mulyani, countercyclical policies are needed to maintain economic stability, when facing various economic challenges in 2020.[4] In regards to the goal, the Ministry of Economy will carry out a number of policies, one of which is the regulation of national 
economic stimulus by restructuring credit financing for debtors affected by the COVID-19. The legal basis for making this countercyclical policy is Act Number 7 of 1992 concerning Banking as amended by Act Number 10 of 1998; Act Number 21 of 2008 concerning Islamic Banking; and Act Number 21 of 2011 concerning the Financial Services Authority.

The implementation of the stimulus policy can be observed by the HIMBARA (Association of State Banks; Himpunan Bank Negara),[5] [6] which supports government policies in overcoming the impact of covid-19 by issuing restructuring or relief announcements for debtors affected by covid- 19 .

TABLE I. LIST OF BANKS THAT SUPPORT THE FINANCING RESTRUCTURING STIMULUS

\begin{tabular}{|l|l|c|l|l|l|}
\hline No & Nama Bank & No & Nama Bank & No & Nama Bank \\
\hline 1 & Mandiri & 17 & Bank Capital & 33 & ICBC \\
\hline 2 & BRI & 18 & bank Bukopin & 34 & JP Morgan \\
\hline 3 & BNI & 19 & Bank Mega & 35 & OK Bank \\
\hline 4 & Panin Bank & 20 & Bank Mayora & 36 & MNC Bank \\
\hline 5 & BCA & 21 & UOB & 37 & KEB Hana \\
\hline 6 & CIMB Niaga & 22 & Bank Fama & 38 & ShinhanBank \\
\hline 7 & Permata Bank & 23 & Bank Mayapada & 39 & hina \\
\hline 8 & OCBC NISP & 24 & Mandiri tanspen & 40 & BNP Paribas \\
\hline 9 & Bank BPTN & 25 & resona perdania & 41 & JasaJakarta \\
\hline 10 & DBS & 26 & Bank BKE & 42 & Bank Index \\
\hline 11 & BankGanesha & 27 & BRI agro & 43 & Bank Artos \\
\hline 12 & $\begin{array}{l}\text { Nobunasional } \\
\text { Bank }\end{array}$ & 28 & Bank SBI & 44 & Bank INA \\
\hline 13 & Bank Victoria & 29 & AGI bank & 45 & BankMestika \\
\hline 14 & BankSampoerna & 30 & commonwealtbank & 46 & Bank Mas \\
\hline 15 & IBK Bank & 31 & HSBC & 47 & CTBC Bank \\
\hline 16 & Sinarmas & 32 & Maybank & & \\
\hline SOURCE: OJK UPDATE No. 05-SPI(BANK UMUM) & & & Bank \\
\hline
\end{tabular}

On Table 1, it can be seen that almost all banks in Indonesia support the stimulus policy by providing restructuring for debtors affected by Covid-19. Debtors affected by covid-19 can apply for restructurization by submitting the following submissions:[7]

1) The debtor is required to submit a restructuring application to the bank where the credit is applied

2) The bank will conduct an assessment of the customer's condition to determine whether they are classified in heavy, medium, or light restructuring

3) the bank determines the debtor restructuring in accordance with the circumstance of the debtor's capability
The countercyclical policy as a response of COVID-19 outbreak is implemented while still paying attention to the precautionary principle and a monitoring mechanism to prevent abuse in the application of provisions (moral hazard). [8] [9] With due observance of the precautionary principle contained in Article 29 paragraph (2) of Law Number 10 of 1998 concerning Amendments to Law Number 7 of 1992 Concerning Banking, FSA shall monitor the risks associated with credit implementation restructuring. This monitoring must be carried out prudently; therefore, the restructuring may be provided to the apt debtor following Article 5 and Article 6 of POJK Number 11/2020, which stipulates that :

Article 5

(1) The quality of restructured credit or financing is determined to be prevailing since the restructuring is carried out.

(2) (2) Credit or financing restructuring as referred to in paragraph (1) can be carried out on credit or financing provided before or after the debtor is affected by the spread of the coronavirus disease 2019 (COVID-19), including micro, small and medium business debtors.

(3) Credit for a BPR or financing for a restructured BPRS is exempted from the application of the accounting treatment for restructured credit or financing.

\section{Article 6}

The provisions referred to in Article 5 apply to credit or financing that meets the following requirements:

a. granted to debtors affected by the COVID-19 outbreak, including micro, small, and medium business debtors; and

b. restructured after debtors were affected by the spread of coronavirus disease 2019 (COVID-19), including micro, small, and medium business debtors

TABLE II. REALIZATION OF BANK CREDIT RESTRUCTURING POLICY

\begin{tabular}{|c|c|c|c|}
\hline \multirow{2}{*}{ Tanggal } & \multicolumn{2}{|c|}{ Debitur } & \multirow{2}{*}{ Jumlah } \\
\hline & UMKM & Non UMKM & \\
\hline \multirow{3}{*}{$\begin{array}{c}7 \\
\text { September } \\
2020\end{array}$} & 5,82 million & 1,56 million & 7,38 million \\
\hline & \multicolumn{2}{|c|}{ Nilai } & \\
\hline & 360,6 trillion & 523,9 trillion & 884,5 trillion \\
\hline \multirow[t]{3}{*}{$\begin{array}{c}5 \text { Oktober } \\
2020\end{array}$} & 5,88 million & 1,65 million & 7,53 million \\
\hline & \multicolumn{2}{|c|}{ Nilai } & \\
\hline & 361,98 trillion & 552,69 trillion & 914,65 trillion \\
\hline
\end{tabular}

Table 2 signifies that the bank has carried out the implementation of the stimulus policy. From September to 
November, debtors saw an increase in credit restructuring proposals. In September, it was recorded that 7.38 million debtors were applying for credit restructuring. It covered MSME debtors for around 5.82 million and non-MSMEs for 1.56 million. There were 7.53 million debtors in October, comprised of 5.88 million MSME debtors and 1.65 million non-MSME debtors.

\section{B. The effectiveness of stimulus policies, which intends to support debtors affected by COVID-19}

A statutory regulation's effectiveness occurs if the code is viewed from the main aspects that focus on the community's interests,[10] then POJK Regulation No. 11/POJK.03/2020 is declared to be effective if this stimulus policy can support economic growth and relieve debtors affected by COVID-19. The criteria for effectiveness are examined from to which extent both the bank and the debtor can utilize the stimulus's frequency. Effectiveness can be regarded both quantitatively and qualitatively. Quantitatively, it is observed from the debtor who proposes to restructure the quality of credit or financing.

Article 10 POJK Regulation No. 11/POJK.03/2020 specifies the implementation of policies that promote economic growth stimulus for debtors, including micro, small and medium business debtors, valid until March 31, 2021. However, based on the press release issued by OJK on November 2, 2020,[11] OJK will extend the restructuring relaxation policy. OJK assesses that the stability of the financial services sector is maintained adequately due to a number of policies that have been executed, including granting bank credit restructuring, [12] therefore they decided to extend the period of relaxation for bank credit restructuring for a year starting from March 2021 to March 2022.

If this countercyclical policy is extended, it needs to be assessed and customized. Currently POJK No. 11/2020 is effectively used both from a debtor and banking perspective. However, concerns arise if the restructuring stimulus policy is extended whether it can still be said to be effective, because there are fears that there are flaws that could harm both debtors and creditors.

Some examples of the weaknesses of this policy are:

1. Regarding long-term restructuring, whether it will benefit the debtor, because the longer the credit period will definitely have an impact on loan interest

2. whether the application of submitting new funds has been carried out properly in accordance with Article 6 POJK $11 / 2020$ because all decisions are returned to the bank, it is not certain that the debtor who proposes new funds can be approved because they still have a credit liability.

(1)Banks may provide credit or financing and / or other new provision of funds to debtors who are affected by the spread of coronavirus disease 2019 (COVID-19), including debtors for micro, small and medium enterprises.

(2) Determination of the quality of credit or financing and / or other new provision of funds as referred to in paragraph (1) shall be conducted separately from the quality of credit or financing and / or other provision of funds previously granted.

(3) Determination of the quality of credit or financing and / or other new provision of funds as referred to in paragraph (1):

a.for credit or financing and / or other new provision of funds with a maximum ceiling of Rp.10,000,000,000.00 (ten billion rupiah), determination of the quality of credit or financing and / or other provision of funds as referred to in Article 3 paragraph (1) or Article 4 paragraph (1); or

b. for credit or financing and / or other new provision of funds with a ceiling of more than Rp.10,000,000,000.00 (ten billion rupiah), the determination of the quality of credit or financing and / or other provision of funds is in accordance with the provisions of the Financial Services Authority regulations regarding quality assessment asset.

3. The emergence of criminal acts such as bad debts and fictitious receivables, the banking regulation distinguishes criminal sanctions into two forms, namely crime and violation. [13] Bad credit in banking regulations is a violation, bad credit can be resolved based on non-litigation and litigation channels, the litigation channel is the last resort in reaching a settlement, fictitious accounts receivable. In accordance with Article 6 POJK / 11/2022, it is feared that there will be debtors using fictitious receivables. if the debtor uses fictitious receivables or documents that mislead the creditor in applying for a new credit, then the act can be punished under the provisions of Article 378 of the Criminal Code concerning fraud. In addition, it may also be subject to Article 263 concerning letter forgery. [14] [15]

\section{CONCLUCION}

Based on the discussion in the previous chapter, it can be concluded that:

1. The implementation of the Financial Services Authority's National economic stimulus policy, both state-owned banks and private banks, implements government policies in the provisions of POJK No. 11 / POJK.03 / 2020. The OJK mechanism accommodates flexibility for banks that promote national economic stimulus by observing the principle of prudence in restructuring credit for debtors, including micro, small and medium enterprises.

2. The effectiveness of stimulus policies that support economic growth for debtors affected by COVID-19 is considered effective in terms of quantity and quality. In terms of quality, it can be viewed from the great number of debtors who have taken advantage of this regulation by proposing restructuring. Furthermore, in terms of quality, debtors feel encouraged by credit restructuring, and the bank can stabilize state finances.

\section{ACKNOWLEDGMENT}

The researcheres would like to say thank you for the Institution of Research and Community Service in Stikubank University Semarang by supported this research 


\section{REFRENCES}

[1] Muhammad Sahirul Alim, 2014, skripsi : Karakter Kebijakan (Procyclicalvs Countercyclical) Dan Stabilitas Makroekonomi :Studiempiris Asian Emerging Economiesperiode 2000 -2012,Semarang: UNDIP Hal. 4

[2] Pasal 10 POJK/11/2020

[3] Jhony Ibrahim. Theori dan Metodologi Penelitian Hukum Normatif. (Malang: Bayu Media.2006).

[4] https://news.ddtc.co.id/sri-mulyani-andalkan-kebijakan-counter-cyclicaltahun-ini-apa-itu-18635?page_y=1353

[5] OJK Updtae 31 Maret 2020-Bank Umum

[6] Enzekoura Laounia, 2014, Restructuring of Banking: Concept, Justifications, Stages and Results, Mediterranean Journal of Social Sciences

[7] OJK Updtare 31 maret 2020-bank Umum

[8] Peter Amire, 2016, The Effect of Corporate External Restructuring on the Performance of Financial Institutions in Nigeria: A Review. International Journal of Economics and Financial Modelling, International Journal of Finance \& Economics Vol. 1(1): 1-11

[9] Alexander Ehimare Omankhanlen, Johnson I. Okoh , Felix N. Ezeji , Esther Ibileke, 2020, Impact of corporate restructuring on the financial performance of commercial banks in Nigeria, Business respectives Volume 152020
[10] Barda Nawawi Arief, 2010, Kebijakan Legislatif dalam penanggulangan kejahatan dengan pidana penjara, Yogyakarta : Genta Publishing

[11] Kloemp, J., and J. de Haan (2015), Bank Regulation, the Quality of Institutions, and Banking Risk in Emerging and Developing Countries: An Empirical Analysis. Emerging Markets Finance and Trade 50(6):1940

[12] Kerlin, J., Malinowska-Misiąg, E., Smaga, P., Witkowski, B., Nowak, A.K., Kozłowska, A., Wiśniewski, P., 2016, European Bank Restructuring During the Global Financial Crisis, Palgrave Macmillan Studies in Banking and Financial Institutions

[13] https://www.ojk.go.id/id/berita-dan-kegiatan/siaranpers/Pages/Kebijakan-Restrukturisasi-Kredit-Jaga-Stabilitas-SektorJasa-Keuangan.aspx

[14] Hana Faridah. Jenis-Jenis Tindak Pidana Perbankan Dan Perbandingan Undang-Undang Perbankan. Jurnal Hukum POSITUM Vol. 3, No. 2, Desember2018

[15] Felisitas Defung, 2020, Factors Determining The Productivity Of Indonesian Banks During Restructuring Period, Journal of Critical Reviews Vol 7, Issue 12, 2020 